\title{
Variable Speed Photovoltaic Water Pumping Using Affinity Laws
}

\author{
Ahmed Moubarak, Gaber El-Saady, El-Noby A. Ibrahim \\ Electrical Engineering Department, Faculty of Engineering, Assiut University, Assiut, Egypt \\ Email:ahmedalaa.ck7@gmail.com,gaber1@yahoo.com
}

How to cite this paper: Moubarak, A., El-Saady, G. and Ibrahim, E.N.A. (2017) Variable Speed Photovoltaic Water Pumping Using Affinity Laws. Journal of Power and Energy Engineering, 5, 50-71. https://doi.org/10.4236/jpee.2017.511005

Received: October 26, 2017

Accepted: November 25, 2017

Published: November 28, 2017

Copyright ( 92017 by authors and Scientific Research Publishing Inc. This work is licensed under the Creative Commons Attribution International License (CC BY 4.0).

http://creativecommons.org/licenses/by/4.0/

(c) (i) Open Access

\begin{abstract}
Photovoltaic (PV) power is most commonly used for water pumping applications. The DC output voltage of PV arrays is connected to a DC-DC converter using a maximum power point tracking (MPPT) controller to maximize their produced energy. Then, that converter is linked to a voltage source inverter (VSI) that converts DC power to AC power. Vector control is used to control the VSI fed three phase induction motor driving the water pump. The Affinity laws are used to change the pump characteristics by changing the pump speed, and consequently, the pump flow rate, head, and power will be varied. In this paper, the Affinity laws are adapted to achieve the pump hydraulic requirements while the power delivered to the pump motor remains unchanged by constructing new pump curves. A Matlab/Simulink model of the PV pumping system is observed over a wide range of weather and loading conditions.
\end{abstract}

\section{Keywords}

Photovoltaic Power, Indirect Field Oriented Control, Three Phase Induction Motor, Centrifugal Pump, Affinity Laws

\section{Introduction}

Photovoltaic energy represents an eco-friendly source of power. It offers an excellent solution for providing sustainable and clean energy to remote and rural areas. Over the past decade, several major advances have been made in solar cells design, and large scale manufacturing techniques, as well as new developments in system component technology. These, in turn, have resulted in a dramatic cost reduction for solar applications which have made solar generation rivals established fuel technologies as a cleaner, more economical choice. Nowadays, solar water pumping system costs have dropped by two-thirds compared to ten 
years ago, as prices of PV modules have reduced by more than $80 \%$ while fuel prices have rose to over $250 \%$. Other than being economically competitive, solar water pumping systems are more reliable and require less maintenance. Due to these benefits, solar water pumping for irrigation, livestock, and domestic use has become the most common PV application and is now widely deployed not only for small farms/ranches but also for large-scale irrigation schemes. With countries even announcing ambitious targets for solar pump installations over the next decade [1] [2]. In order to obtain an efficient system, the PV modules must operate at the maximum power point (MPP) which allows the modules to produce all the power they are capable of based on the variation in the irradiation and temperature. Several methods for maximum power point tracking (MPPT) have been discussed over the years [3] [4]. The most popular of these methods are searching based techniques such as Perturb and Observe (P \& O) and Incremental Conductance (IC) methods. The DC-DC converters are widely used in photovoltaic supply applications where the input voltage to these converters varies widely due to the unpredictability and variation in the solar irradiation level and cell operating temperature. Basic converter topologies include Buck, Boost, Buck-Boost, Cuk and full-bridge converter [4] [5]. Several studies have investigated the use of DC motor pumps [6]. However, they suffer from maintenance problems due to the presence of the commutator and brushes. So induction motors have been an attractive alternative as they are reliable and require less maintenance [7] [8]. Often the water pump output is changed to either control the water pressure in the pipes or maintain the water level at the receiving end. Although there are many methods for controlling the pump operation which include control valves, bypass and varying the number of parallel connected pumps, the most effective method is variable speed pumping [9]. The Affinity laws are used to change the pump characteristics by changing the pump speed, and consequently, the pump flow rate, head, and power will be varied [10]. Several papers have investigated the use of the Affinity laws for energy saving purposes, as the pump power required decreases when the flow rate decreases [6] [11] [12] [13]. The proposed method differs from the others where the Affinity laws are investigated when the power delivered to the pump is constant. So the Affinity laws are adapted to achieve the required varying hydraulic requirements while the power delivered to the pump motor remains unchanged by constructing new pump performance curves. Also, the system performance is simulated and analyzed for different weather conditions.

This paper is organized into sections as follows: In the first section, a basic introduction is given which includes a review of the existing research on the PV water pumping systems and its components, and shows where the proposed method is different. Section two presents an overview of the proposed system. Mathematical modeling and design of the system components are demonstrated in Section three. In Section four, the proposed method is illustrated. Also, the simulation results and characteristics are presented for two modes of operation 
(flow rate variation mode and pumping head variation mode) under varying weather conditions. Finally, Section five concludes the paper with merits of the proposed system.

\section{Overview of the Proposed System}

The photovoltaic water pumping system shown in Figure 1 consists of:

- PV Array that converts the solar irradiation into DC power.

- Boost DC-DC Converter which boosts up the PV voltage to the predetermined levels.

- Maximum Power Pont Tracking (MPPT) that tracks the optimized operation point for power extraction by controlling the boost converter duty cycle.

- Inverter that converts the DC power to AC power.

- Motor Control Unit that controls the speed and torque of the induction motor using field oriented control which in turn controls the pump performance.

- Motor-Pump set which is a centrifugal pump that is driven by a three phase induction motor.

\section{Modeling of Proposed Electrical Model}

\subsection{Photovoltaic Model}

A general mathematical description of I-V output characteristics for a PV cell has been studied for quite some time as in [14]. Such an equivalent circuit-based model is mainly used for the MPPT technologies. The equivalent circuit of the general model which consists of a photo current $\left(I_{L}\right)$, a diode $(D)$, a parallel resistor $\left(R_{s h}\right)$ expressing a leakage current, and a series resistor $\left(R_{s}\right)$ describing an internal resistance to the current flow, is shown in Figure 2.

The equation that describes the current $(I)$-voltage $(V)$ relationship of the PV cell [14]:

$$
I=I_{L}-I_{o}\left\{\mathrm{e}^{\frac{q\left(V+R_{s} I\right)}{n K T}}-1\right\}-\frac{V+R_{s} I}{R_{s h}}
$$

where $q$ is the electron charge; $I_{o}$ is the reverse saturation current; $n$ is the diode ideality factor; $k$ is the Boltzmann's constant; and $T$ is cell temperature.

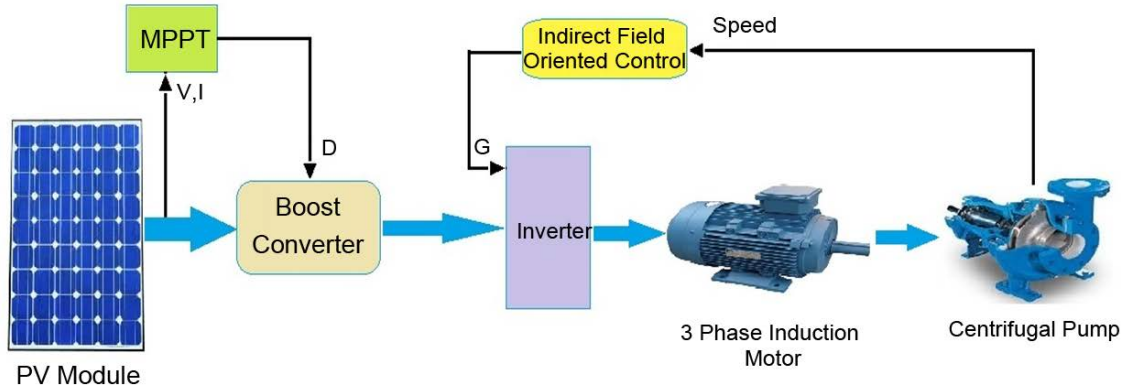

Figure 1. Proposed photovoltaic water pumping system. 
In this paper, Auxin Solar (AXN-P6T170) PV module is taken as the reference module for simulation and it has the following electrical specifications which are taken from the datasheet [15] as shown in Table 1.

These electrical specifications are provided with reference to standard test conditions (STC) of irradiance of $1000 \mathrm{~W} / \mathrm{m}^{2}$, spectrum of 1.5 air mass and cell temperature of $25^{\circ} \mathrm{C}$

In order to meet the load needs, the PV array consists of 5 series-connected modules per string and 5 parallel strings.

\subsection{Maximum Power Point Tracking (MPPT)}

\section{Perturb and Observe (P \& 0)}

The P \& O algorithm [3] [4] involves a perturbation on the duty cycle of the power converter and a perturbation in the operating voltage of the DC-link between the PV array and the power converter. As can be seen in Figure 3, on the left of the MPP incrementing the voltage increases the power whereas on the right decrementing the voltage decreases the power. If there is an increment in the power, the perturbation should be kept in the same direction and if the power decreases, then the next perturbation should be in the opposite direction. The sign of the last perturbation and the sign of the last increment in the power are used to decide the next perturbation.

The algorithm is shown in Figure 4, where the process is repeated until the MPP is reached. The operating point oscillates around the MPP.

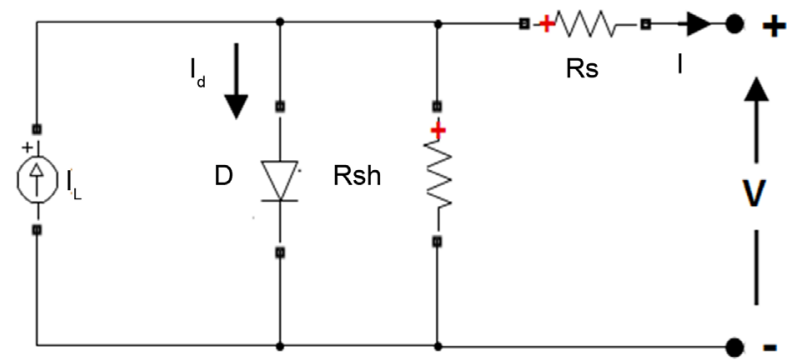

Figure 2. Equivalent circuit of a PV cell.

Table 1. Electrical characteristics data of pv module taken from the datasheet [15].

\begin{tabular}{cc}
\hline Parameter & Value \\
\hline Maximum power & $169.932 \mathrm{~W}$ \\
Open circuit voltage (Voc) & $28.8 \mathrm{~V}$ \\
Voltage at maximum power point $(\mathrm{Vmpp})$ & $23.8 \mathrm{~V}$ \\
Temperature coefficient of $\operatorname{Voc}(\beta)$ & $0.37\left(\% /{ }^{\circ} \mathrm{C}\right)$ \\
Cells/Module & 48 \\
Short circuit current $(\mathrm{Isc})$ & $7.72 \mathrm{~A}$ \\
Current at maximum power point $(\mathrm{Impp})$ & $7.14 \mathrm{~A}$ \\
Temperature coefficient of Isc $(\alpha)$ & $0.111\left(\% /{ }^{\circ} \mathrm{C}\right)$
\end{tabular}




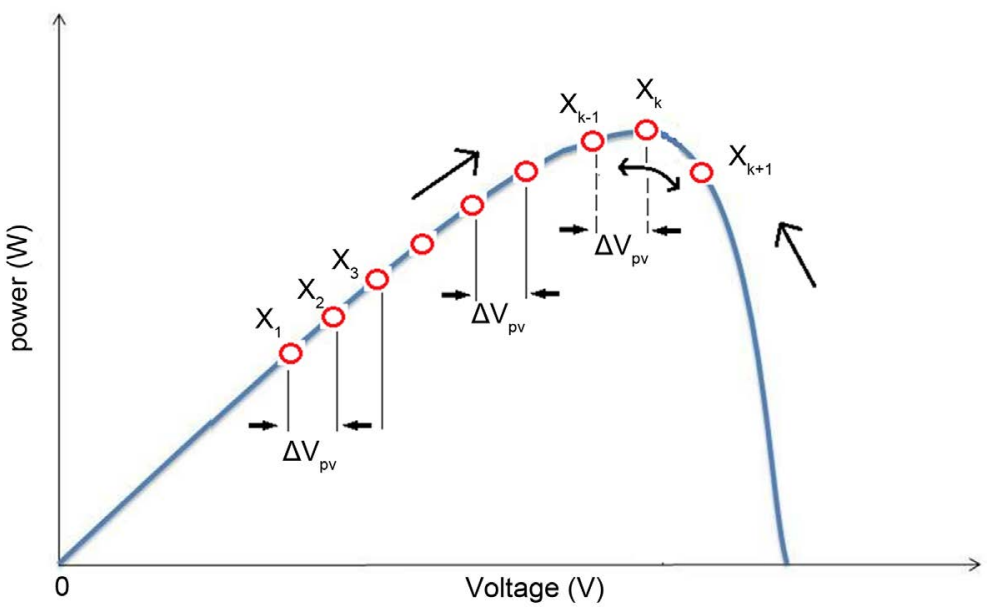

Figure 3. Operation of perturb and observe algorithm.

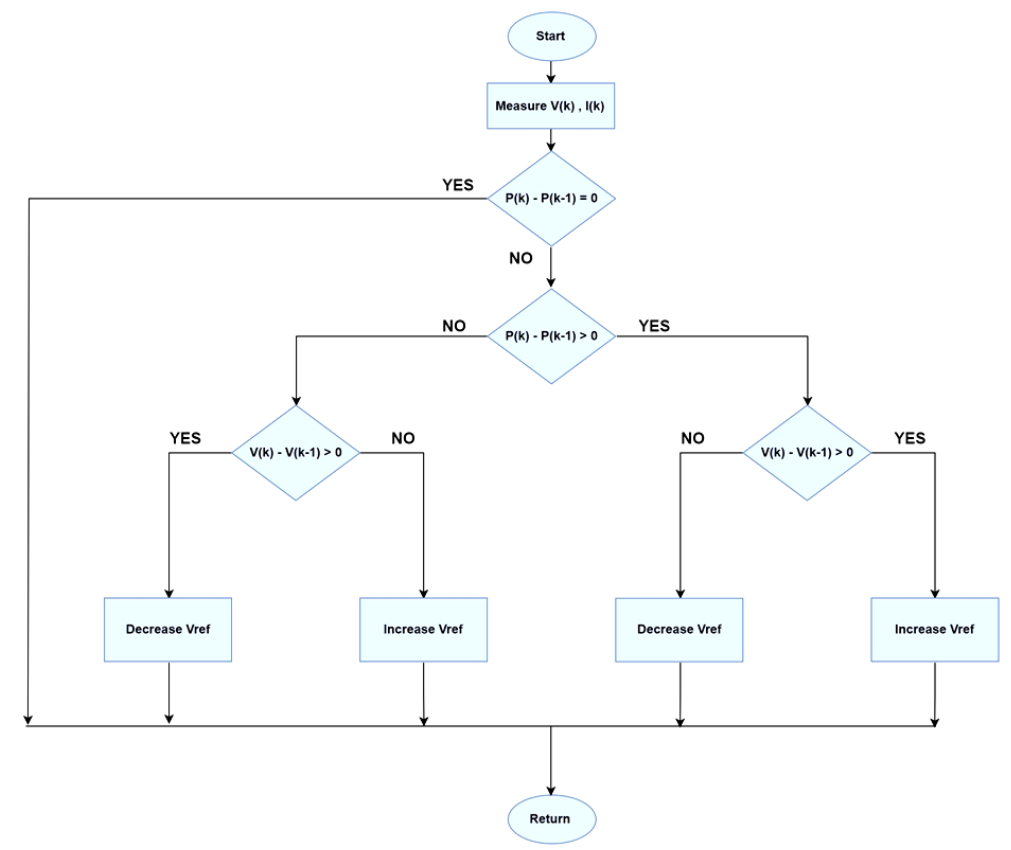

Figure 4. Flowchart of the perturb and observe algorithm.

\subsection{DC-DC (Switch Mode) Converter}

DC-DC converters are used to interface the photovoltaic modules with the load, in order to ensure the photovoltaic modules are always operating at the MPP. This is done by controlling the converter duty ratio $(D)$ with MPPT algorithms [4] [5].

\section{Step-Up (Boost) Converter Design}

In this type of converter, the output voltage $\left(V_{o}\right)$ is always greater than the input voltage $\left(V_{d}\right)$. The circuit configuration is shown in Figure 5.

The boost converter inductor $(L)$ can be calculated [16] as:

$$
L=\frac{V_{d} D T_{s}}{\Delta I_{L}}
$$




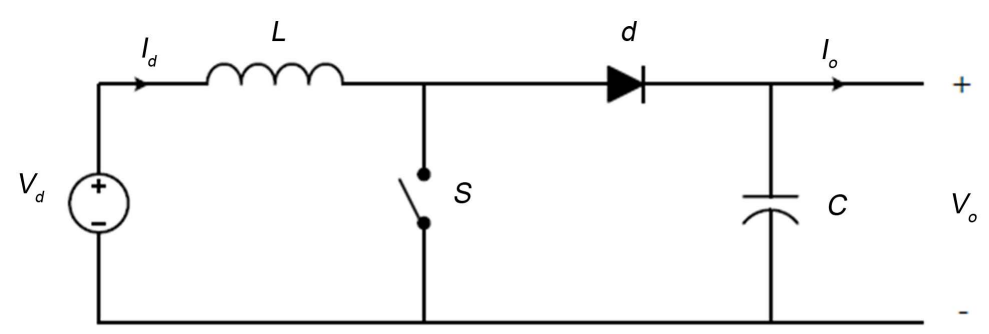

Figure 5. Step-Up (Boost) converter configuration.

According to the IEC harmonic Standard [17], it is recommended to choose the inductor current ripple factor (CRF) between $(20 \%-40 \%)$. Choosing the inductor ripple current $\left(\Delta I_{L}\right)$ closer to $20 \%$ of the average inductor current $\left(I_{L}\right)$ results in a larger inductance value which maximizes the converter's potential output current and minimizes the electromagnetic interference (EMI). Choosing $\Delta I_{L}$ closer to $40 \%$ of $I_{L}$ results in a smaller inductance value, and a physically smaller inductor which improves the transient response but results in a potentially higher EMI and lower efficiency.

In this paper, the CRF is chosen as $\frac{\Delta I_{L}}{I_{L}}=30 \%$, where $I_{L}=I_{d}$.

The boost converter capacitor $(C)$ can be calculated [16] as:

$$
\therefore C=\frac{I_{o} D T_{S}}{\Delta V_{o}}, \text { where: } \frac{\Delta V_{o}}{V_{o}}=5 \%
$$

The input filter capacitor $\left(C_{i n}\right)$ can be calculated [16] as follows:

$$
C_{i n} \geq \frac{I_{o} \times D^{2}}{\frac{\Delta V_{o}}{V_{o}} \times(1-D) \times V_{d} \times f_{s}}
$$

where $T_{s} \& f_{s}$ are the inverter switching time and frequency, respectively; $I_{d} \& I_{o}$ are the converter input and output currents, respectively; and $\Delta V_{o}$ is the peak to peak output voltage ripple.

The boost converter parameters which are calculated in continuous current conduction mode are shown in Table 2.

\subsection{Three Phase Induction Motor}

The AC induction motor is widely used in water pumping systems as it is the preferred choice for most variable speed drive applications [7] [8].

\subsubsection{Modeling of Three Phase Induction Motor}

The induction motor is modeled using transformation of fixed abc coordination to rotating dq0 coordination.

The choice of the reference frame for the dynamic analysis of the induction machine, especially when the rotor circuits are unbalanced, is more convenient to be fixed to the rotor frame. This reference frame is in fact the Park's transformation, initially developed for synchronous machine and then applied to the 
Table 2. Boost converter and input filter parameters.

\begin{tabular}{cc}
\hline Parameter & Value \\
\hline Inductor $(L)$ & $4.73 \mathrm{e}^{-3} \mathrm{H}$ \\
Capacitor $(C)$ & $2.26 \mathrm{e}^{-4} \mathrm{~F}$ \\
Input Filter Capacitor $\left(C_{\text {in }}\right)$ & $1.9 \mathrm{e}^{-3} \mathrm{~F}$ \\
\hline
\end{tabular}

induction machine [18]. Referring the machine variables to a rotor reference frame is most useful for field oriented control systems.

\subsubsection{Estimation of Induction Motor Parameters}

The induction motor equivalent circuit parameters are required for many motor performance and planning studies. These parameters are also crucial when considering advanced control techniques (i.e. field oriented control). As the parameters used in the controller must be matched with actual motor parameters to achieve high dynamic response, so precise identification of these parameters is essential.

These parameters are typically calculated from standardized motor performance tests, such as the no load, locked rotor and DC tests [19]. However, in most cases, neither the original test data nor the equivalent circuit parameters are available from the motor manufacturer. And experimental testing may not be available due to the lack of hardware, experience and time required to perform the tests.

In this paper, the method used for induction motor parameters calculation was developed by M. H. Haque [20]. It constructs a set of nonlinear equations that relate the circuit parameters to the motor input power and losses. These equations are then solved by an iterative Gauss-Seidel method. This method requires the nameplate data, the ratio of the starting torque to the full load torque, and both the power factor and efficiency at half \& full load. These can be found from the motor general performance data as provided by the manufacturer [21].

The steps used for Haque's method [20] are as follows:

1) The stator phase currents at full and half load $I_{1 f}$ and $I_{1 h}$, respectively, are calculated from the output power $\left(P_{\text {out }}\right)$, efficiency $(\eta)$, and power factor data, while initial values are assumed for the rotor induced voltage at full and half load $E_{f}$ and $E_{h}$, respectively, the friction and windage losses $\left(P_{\text {Mech }}\right)$, and the rotor phase currents at full and half load $I_{2 f}$ and $I_{2 h}$, respectively [20].

2) The rotor resistance $\left(R_{2}\right)$ is calculated from:

$$
R_{2}=\frac{\left(P_{\text {out }}+P_{\text {Mech }}\right) s_{f}}{3 I_{2 f}^{2}\left(1-s_{f}\right)}
$$

where $s_{f}$ is the full load slip.

The stator resistance $\left(R_{1}\right)$ and the constant losses $\left(P_{\text {Const }}\right)$ are the solution of the linear system formed by applying equation (6) to two load operation points (full and half load). 


$$
\begin{aligned}
& \quad 3 I_{1}^{2} R_{1}+3 I_{2}^{2} R_{2}+P_{\text {Const }}=\frac{P_{\text {out }}}{2}\left(\frac{1}{\eta}-1\right) \\
& \text { where } P_{\text {Const }}=P_{\text {Mech }}+P_{\text {Core }}
\end{aligned}
$$

The core loss resistance $\left(R_{m}\right)$ is calculated from $E_{f}$ and the core power losses $\left(P_{\text {Core }}\right)$ which is equal to half of $P_{\text {Const }}$.

$$
R_{m}=\frac{3 E_{f}^{2}}{P_{\text {Core }}}
$$

$X_{1}$ and $X_{2}$ are the stator and rotor leakage reactances, respectively, and are calculated from:

$$
X_{1}+X_{2}=\sqrt{3 \frac{T_{F L}}{T_{\text {st }}} \frac{V^{2} R_{2}}{P_{\text {out }}}\left(1-s_{f}\right)-\left(R_{1}+R_{2}\right)^{2}}
$$

where $T_{F L}, T_{s t}$ are the full load and starting torques, respectively, and $V$ is the stator phase voltage.

Constant proportionality between $X_{1}$ and $X_{2}$ was applied according to the NEMA motor design categories [19].

The magnetizing reactance $\left(X_{m}\right)$ is calculated from the reactive power balance:

$$
X_{m}=\frac{E_{f}^{2}}{V I_{1 f} \sin \theta_{1 f}-I_{1 f}^{2} X_{1}-I_{2 f}^{2} X_{2}}
$$

3) Update the values of $E_{f}, E_{h}, I_{2 f}, I_{2 h}$, and $P_{\text {Mech }}$.

4) Steps $b$ and $c$ are repeated until convergence.

It has been found that the proposed algorithm converged quickly in about 4 iterations.

The induction motor parameters obtained using Haque's method, are shown in Table 3.

\subsection{Field Oriented Control}

While scalar control method is cheap and easy to implement, it has many drawbacks like slow transient response, low speed accuracy, and it generates oscillations on the produced torque. This is why scalar control is not used in high

Table 3. Three phase induction motor parameters.

\begin{tabular}{cccc}
\hline Parameter & Value & Parameter & Value \\
Rated Power & $4 \mathrm{Kw}$ & Rated Line to Line Voltage & $400 \mathrm{~V}$ \\
Rated Frequency & $50 \mathrm{~Hz}$ & Number of Poles & 4 \\
Stator Resistance & $1.47 \Omega$ & Stator Leakage Reactance & $1.834 \Omega$ \\
Rotor Resistance & $1.393 \Omega$ & Rotor Leakage Reactance & $1.834 \Omega$ \\
Magnetizing Reactance & $54.1 \Omega$ & Moment of Inertia & $0.012 \mathrm{Kg} \cdot \mathrm{m}^{2}$ \\
Rated Speed & $1425 \mathrm{RPM}$ & Rated Torque & $26.8 \mathrm{~N} \cdot \mathrm{m}$ \\
Efficiency & $86.6 \%$ & & \\
\hline
\end{tabular}


performance applications. In order to achieve better dynamic performance, a more superior control scheme is needed. Field oriented control method provides an excellent performance in terms of static and dynamic speed regulation and rapid response to transients. So it satisfies the requirements of dynamic drives [22] [23].

\subsubsection{Indirect Field Oriented Control (IFOC)}

A digital rotor speed sensor is required for indirect field oriented control schemes. The rotor flux angle $\left(\theta_{f}\right)$ for field orientation is obtained from the measured rotor speed and calculated slip angle based on motor parameters [22]. A typical block diagram of the IFOC with current controlled VSI is shown in Figure 6.

\subsubsection{Current Controlled Voltage Source Inverter}

The current regulated VSI can make the inverter output currents $i_{a s}, i_{b s}$, and $i_{c s}$ follow their references $i_{a s}^{*}, i_{b s}^{*}$, and $i_{c s}^{*}$ closely [24] [25]. The controller generates sinusoidal reference current of desired magnitude and frequency which then is compared to the actual motor line current. So the actual current is forced to track the reference current within the hysteresis band. The operating principle of the hysteresis current regulated VSI is illustrated in Figure 7, where the control of only one phase is shown. The hysteresis comparator has a tolerance band of $\delta$.

\subsection{Water Pumping System}

Water pumps are generally classified into two main categories [10]:

Positive displacement pumps.

Rotodynamic pumps.

Rotodynamic pumps are widely used in irrigation. They are of simple construction, the only moving parts being the impeller and shaft.

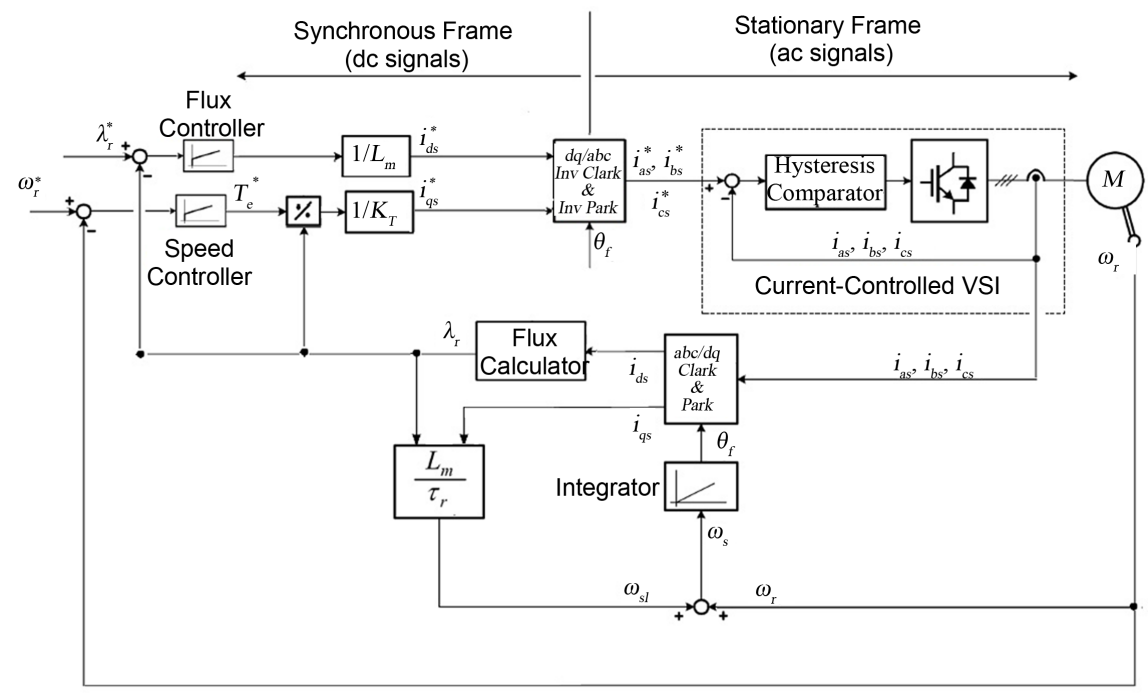

Figure 6. IFOC with a current regulated VSI. 


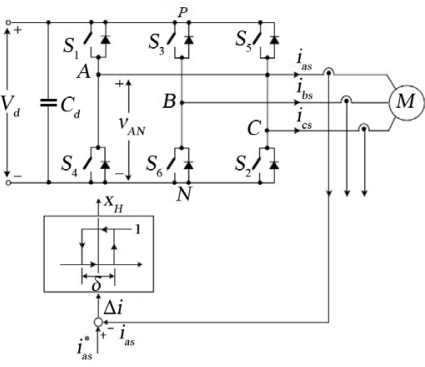

(Inverter and hysteresis comparator)

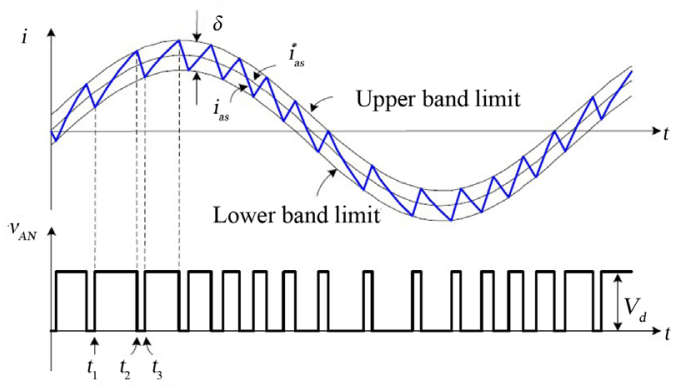

(Tolerance band current control)

Figure 7. Current controlled voltage source inverter.

Centrifugal pumps are used in agriculture and are a good example of the Rotodynamic pump group.

\subsubsection{Centrifugal Pump}

Centrifugal pump converts mechanical energy into pressure energy by means of centrifugal force acting on the fluid. It has relatively high efficiency and are capable of pumping a high volume of water.

Pump manufacturers provide performance characteristics curves which exist for various impeller diameters/constant speed or fixed impeller diameter/variable speed.

The pump used in this study [26], requires $4 \mathrm{Kw}$ motor and a rated speed of $1425 \mathrm{rpm}$.

The following Figure 8 and Figure 9 are the characteristics performance curves of the pump used [26].

\subsubsection{Pump Power Calculation}

The power requirement of the pump depends on the pump and motor efficiency, differential pressure, fluid density, viscosity and flow rate.

- Hydraulic Power:

The hydraulic power output of the pump $\left(P_{H}\right)$ is the power required to lift a volume of water through a given head [10]:

$$
P_{H}(w)=\frac{\rho g H Q}{3600}
$$

where $\rho$ is the fluid density $\left(\mathrm{kg} / \mathrm{m}^{3}\right)$ and $g$ is the gravity acceleration $\left(\mathrm{m} / \mathrm{s}^{2}\right)$. - Shaft Power:

The shaft power $\left(P_{S h}\right)$ is the power supplied by the motor to the pump shaft. Shaft power depends on the pump efficiency $\left(\eta_{P}\right)[10]$ :

$$
P_{S h}(w)=\frac{P_{H}}{\eta_{P}}
$$

\subsubsection{The Affinity Laws}

Processes require the satisfaction of the hydraulic parameters of head and flow rate. The Affinity Laws are mathematical relationships that allow for the estimation of the changes in the pump performance curves as a result of a change in 


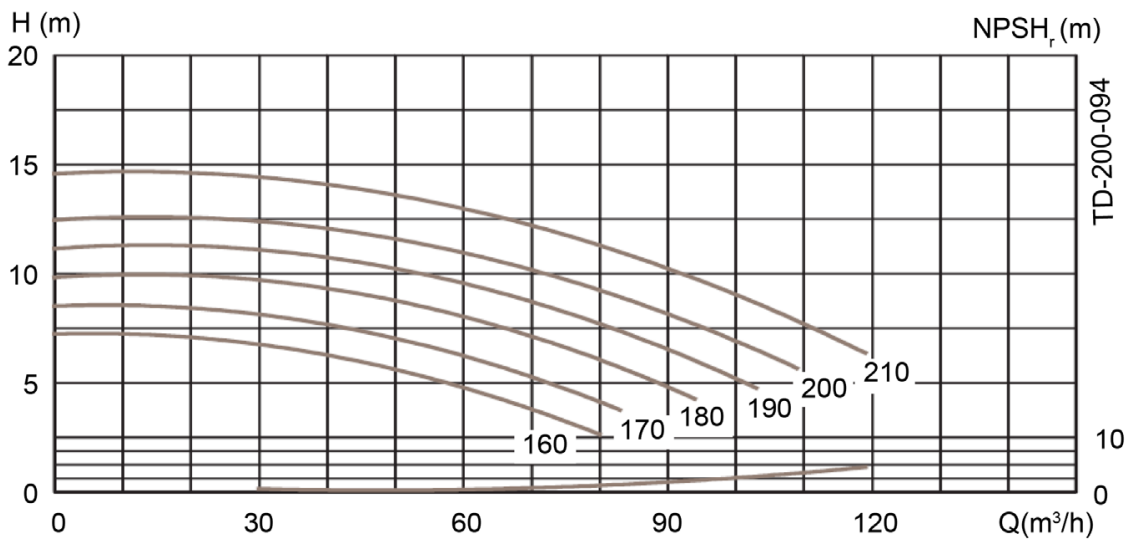

Figure 8. (Head vs. Flow) pump performsance curves (variable impeller diameter, constant speed of 1425 RPM).

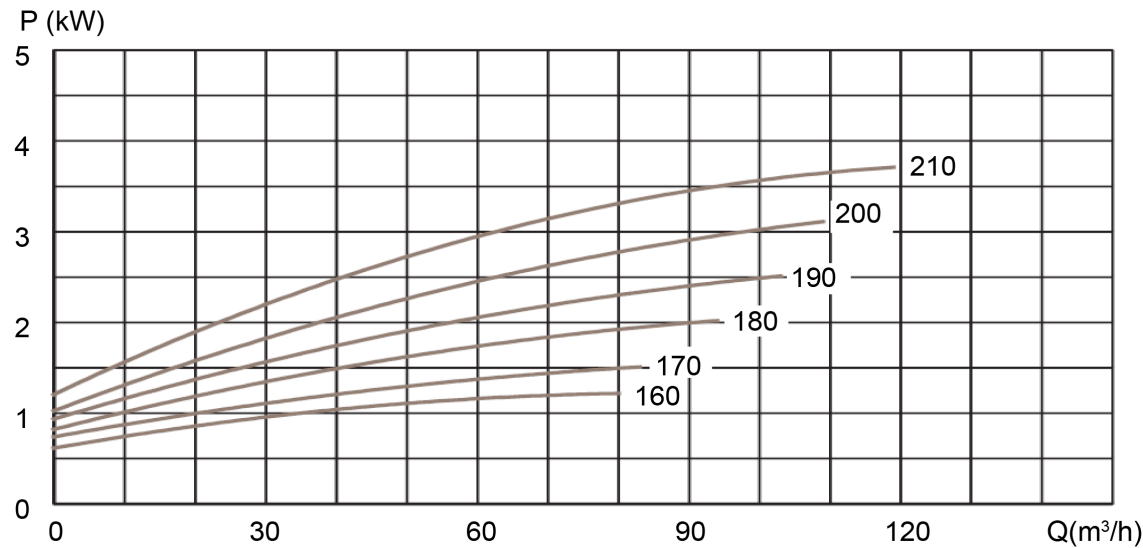

Figure 9. (Power vs. Flow) pump performance curves (variable impeller diameter, constant speed of 1425 RPM).

the shaft speed $(N)$ or in the impeller diameter [10].

Fixing the impeller diameter, the Affinity Laws state that for a given pump, the flow rate $(Q)$ will be directly proportional to the speed, the head $(H)$ will be directly proportional to the square of the speed, and the required power $(P)$ will be directly proportional to the cube of the speed [10] as shown in Figure 10.

$$
\frac{Q_{1}}{Q_{2}}=\frac{N_{1}}{N_{2}}, \frac{H_{1}}{H_{2}}=\left(\frac{N_{1}}{N_{2}}\right)^{2}, \frac{P_{1}}{P_{2}}=\left(\frac{N_{1}}{N_{2}}\right)^{3}
$$

From the Affinity Laws, Figure 11 and Figure 12 show the pump used [26] performance curves at variable speed, and constant impeller diameter $=210 \mathrm{~mm}$.

\section{Simulation \& Results}

\subsection{Simulation Model}

The proposed system is obtained using Matlab/Simulink as shown in Figure 13. The designed system consists of a PV array, a boost converter which its duty cycle is changed by using a MPPT algorithm (Perturb \& Observe) so that the 


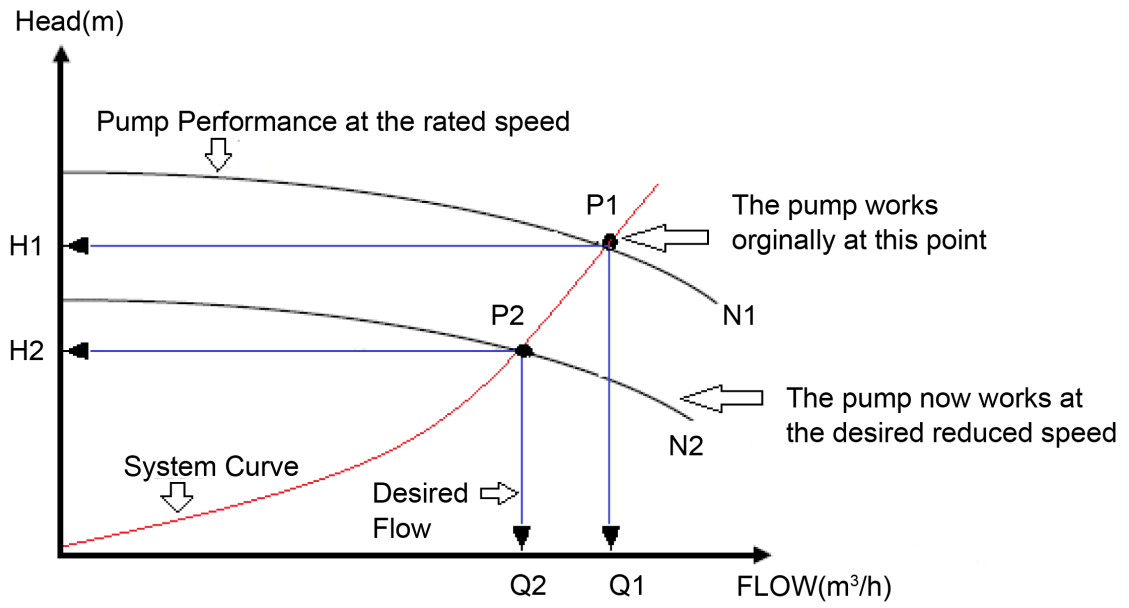

Figure 10. Variable speed pump performance curves.

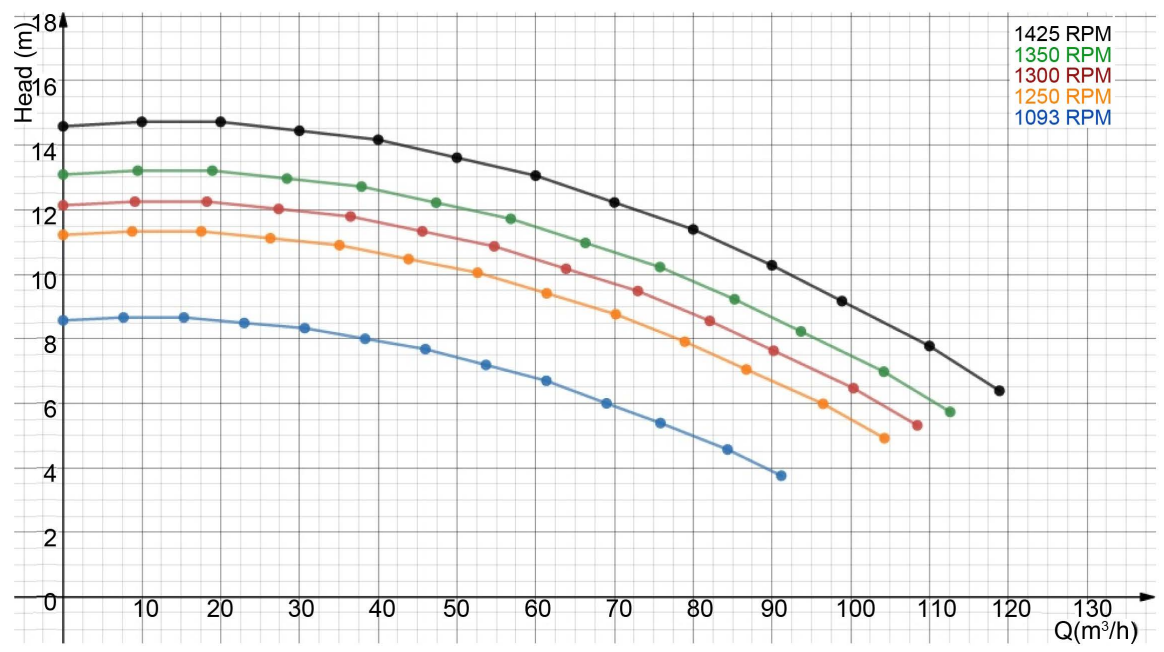

Figure 11. (Head vs. Flow) pump performance curves (variable speed, fixed impeller diameter of $210 \mathrm{~mm}$ ).

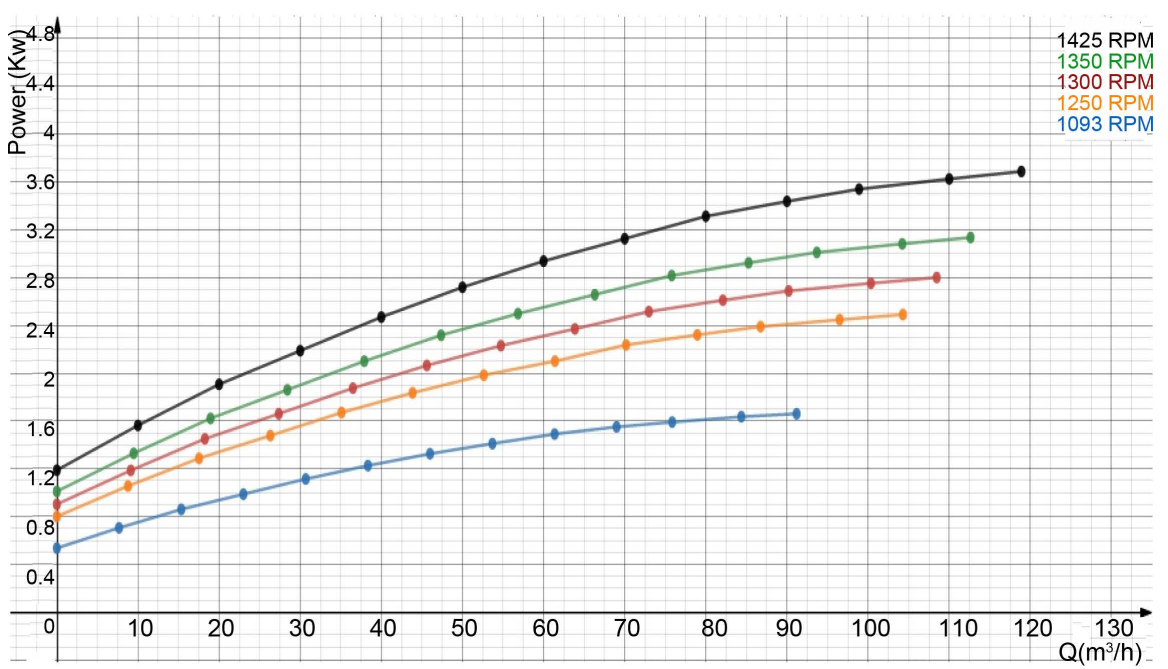

Figure 12. (Power vs. Flow) pump performance curves (variable speed, fixed impeller diameter of $210 \mathrm{~mm}$ ). 


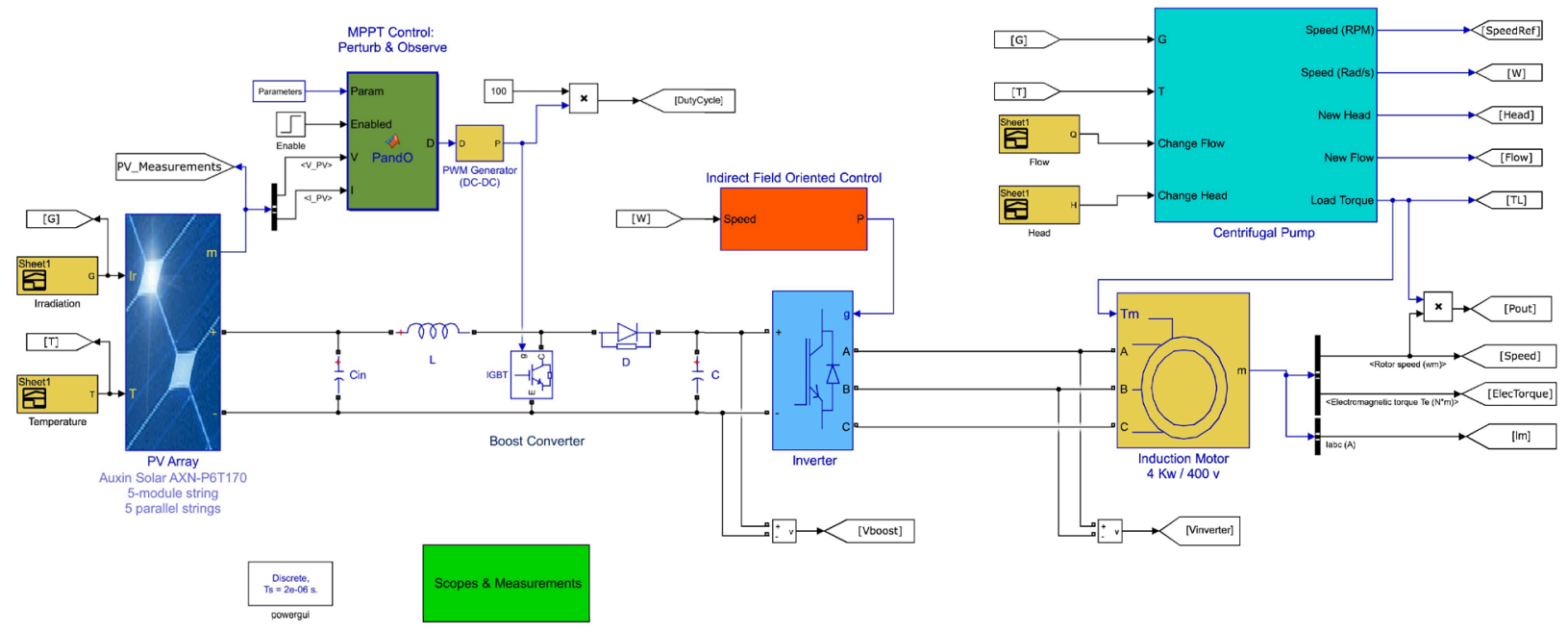

Figure 13. Matlab/Simulink model of PV water Pump.

maximum power from the solar array is extracted, an inverter which is controlled using IFOC, a three phase induction motor and a centrifugal pump model.

Factors affecting the PV system efficiency include: nameplate DC rating, inverter losses, DC-DC converter losses, mismatch, AC \& DC wiring losses, diodes and connection losses, soiling, sun tracking, shading and heating of modules [27]. In this model, the losses account for $15 \%-17 \%$.

Table 4 shows the PV power ( $P p v)$ and motor output power (Pout) at various weather conditions (Irradiation $(G) \&$ Temperature $(T)$ ): where Pout $=P p v-$ losses due to motor efficiency - system losses.

Affinity laws are limited to keep the pump speed below or equal to the rated speed of the motor, and above the speed at which the torque load on the motor is increased over its rated torque. So controller changes the motor speed to accommodate for the required hydraulic performance (flow rate $\&$ head) while the power supplied to the motor is constant.

The proposed method used to satisfy the required pump hydraulic performance using the Affinity laws is implemented in Figure 14.

Figure 15 and Figure 16 are the pump (Head vs Flow) and (Power vs Flow) curves obtained using the proposed method at the weather conditions listed in Table 4.

\subsection{Simulation Results}

The system was simulated in different weather conditions (solar irradiation and temperature) for two modes:

1) Variation of flow rate.

2) Varation of pumping head.

Table 5 shows how the weather conditions (solar irradiation and temperature) are varied throughout the simulation time. 
Table 4. Ppv \& Pout at various weather conditions.

\begin{tabular}{cccc}
\hline$G\left(\mathrm{~W} / \mathrm{m}^{2}\right)$ & $T\left({ }^{\circ} \mathrm{C}\right)$ & $\operatorname{PpV}(\mathrm{W})$ & Pout $(\mathrm{W})$ \\
\hline 1000 & 25 & 4248 & 3069 \\
1000 & 35 & 4085 & 2942 \\
900 & 25 & 3824 & 2735 \\
900 & 35 & 3677 & 2619 \\
\hline
\end{tabular}
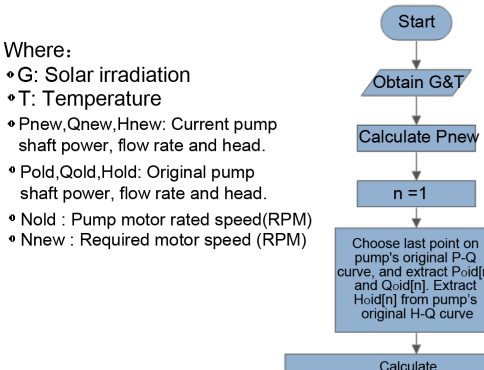

Nnew $[n]=$ Nold $/(\text { Pold }[n] / \text { Pnew })^{1 / 3}$

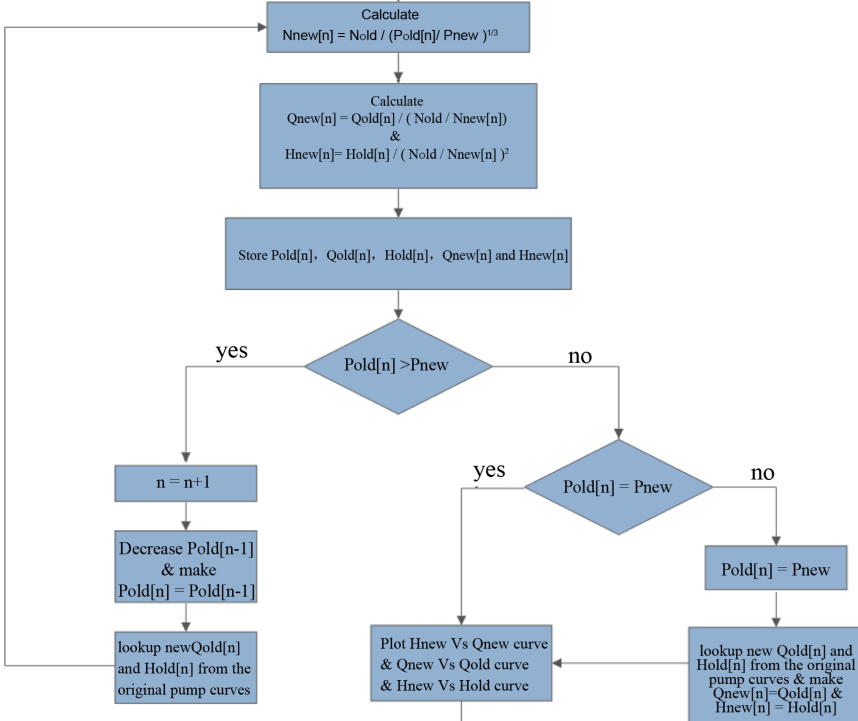

(1) Calculate new curves due to changing of weather conditions (G \& T)
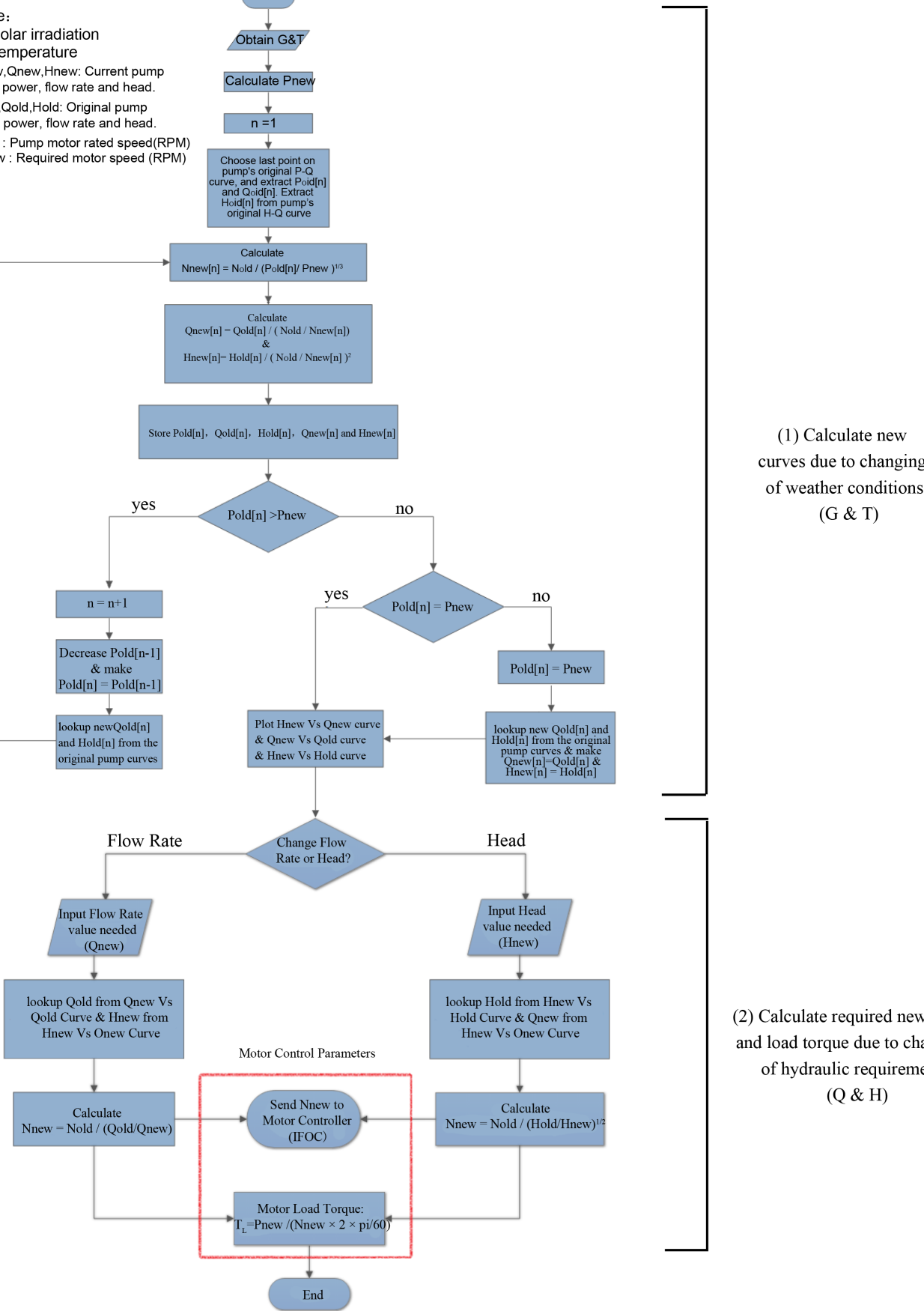


\subsubsection{Flow Rate Variation Mode}

Table 6 shows the variation of motor speed due to weather conditions variation as previously stated in Table 5, and also due to sudden change in flow rate needed. The flow rate is reduced at time $\left(t=3 \mathrm{~s}\right.$ ) from $104 \mathrm{~m}^{3} / \mathrm{h}$ to $67 \mathrm{~m}^{3} / \mathrm{h}$.

The resultant motor speed is the speed at which the flow rate $(Q)$ is kept at the required value even if the weather conditions change.

Table 5. Variation of weather conditions throughout the simulation time.

\begin{tabular}{ccc}
\hline Time (s) & $G\left(\mathrm{~W} / \mathrm{m}^{2}\right)$ & $T\left({ }^{\circ} \mathrm{C}\right)$ \\
\hline $0-2$ & 1000 & 25 \\
$2-2.5$ & 1000 & 30 \\
$2.5-3$ & 900 & 30 \\
$3-3.5$ & 900 & 35 \\
$3.5-4$ & 1000 & 35 \\
$4-5$ & 1000 & 25 \\
\hline
\end{tabular}

Table 6. Motor speed variation to fulfil the required flow.

\begin{tabular}{ccc}
\hline Time $(\mathrm{s})$ & $Q\left(\mathrm{~m}^{3} / \mathrm{h}\right)$ & Speed $(\mathrm{RPM})$ \\
\hline $0-2$ & 104 & 1348 \\
$2-2.5$ & 104 & 1338 \\
$2.5-3$ & 104 & 1283.5 \\
$3-3.5$ & 67 & 1339.7 \\
$3.5-4$ & 67 & 1401.3 \\
$4-5$ & 67 & 1425 \\
\hline
\end{tabular}

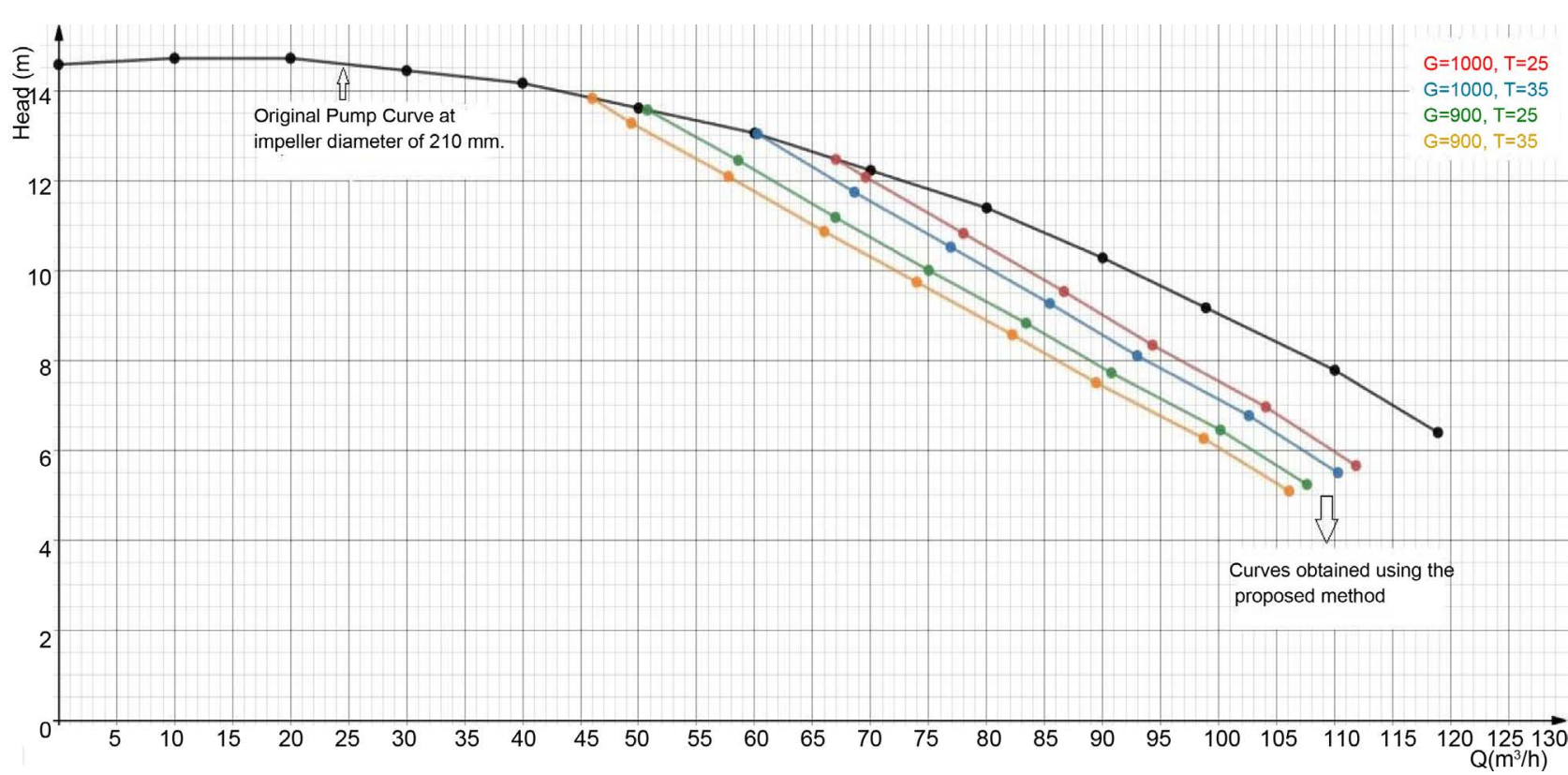

Figure 15. (Head Vs. Flow) curves obtained using the proposed method. 


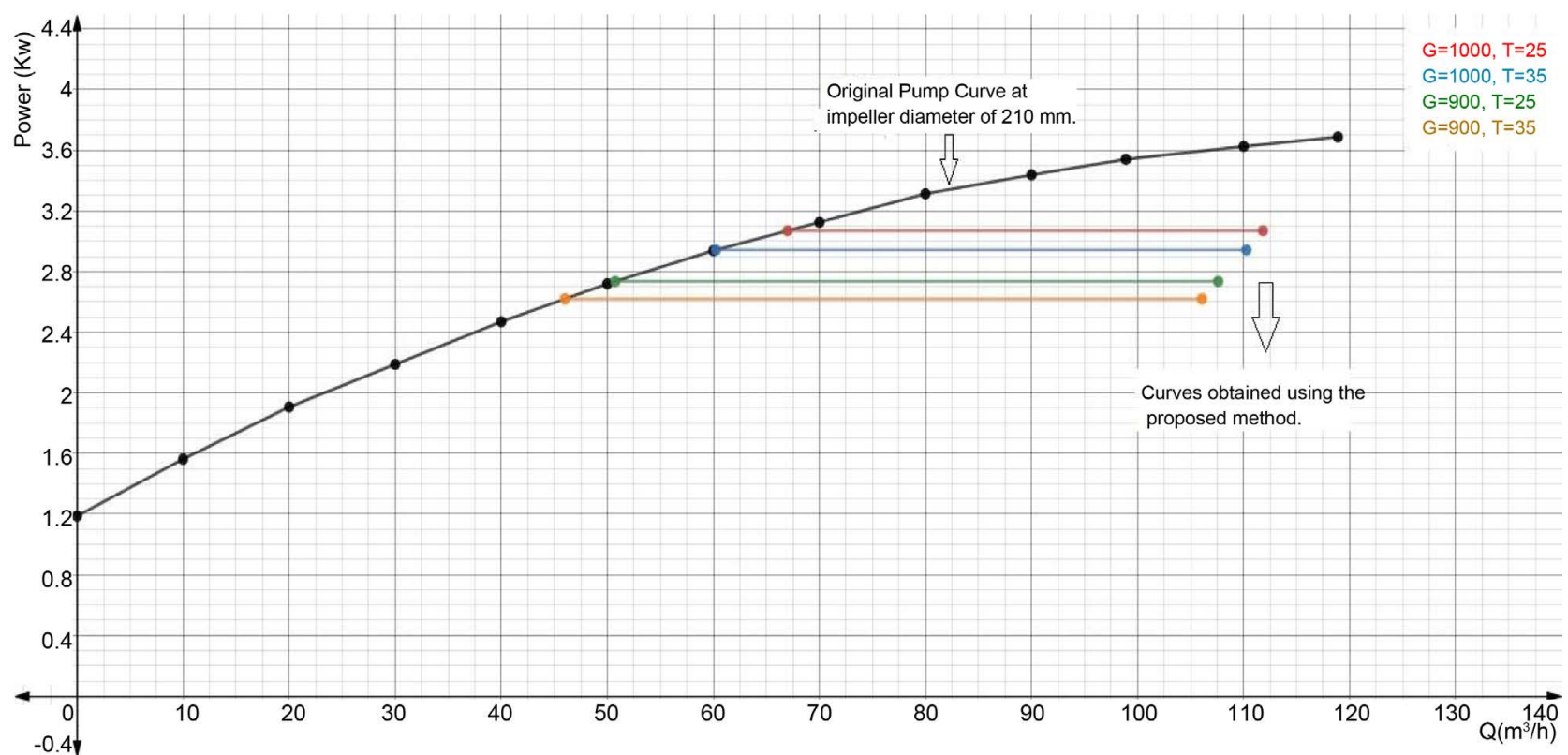

Figure 16. (Power vs. Flow) curves obtained using the proposed method.
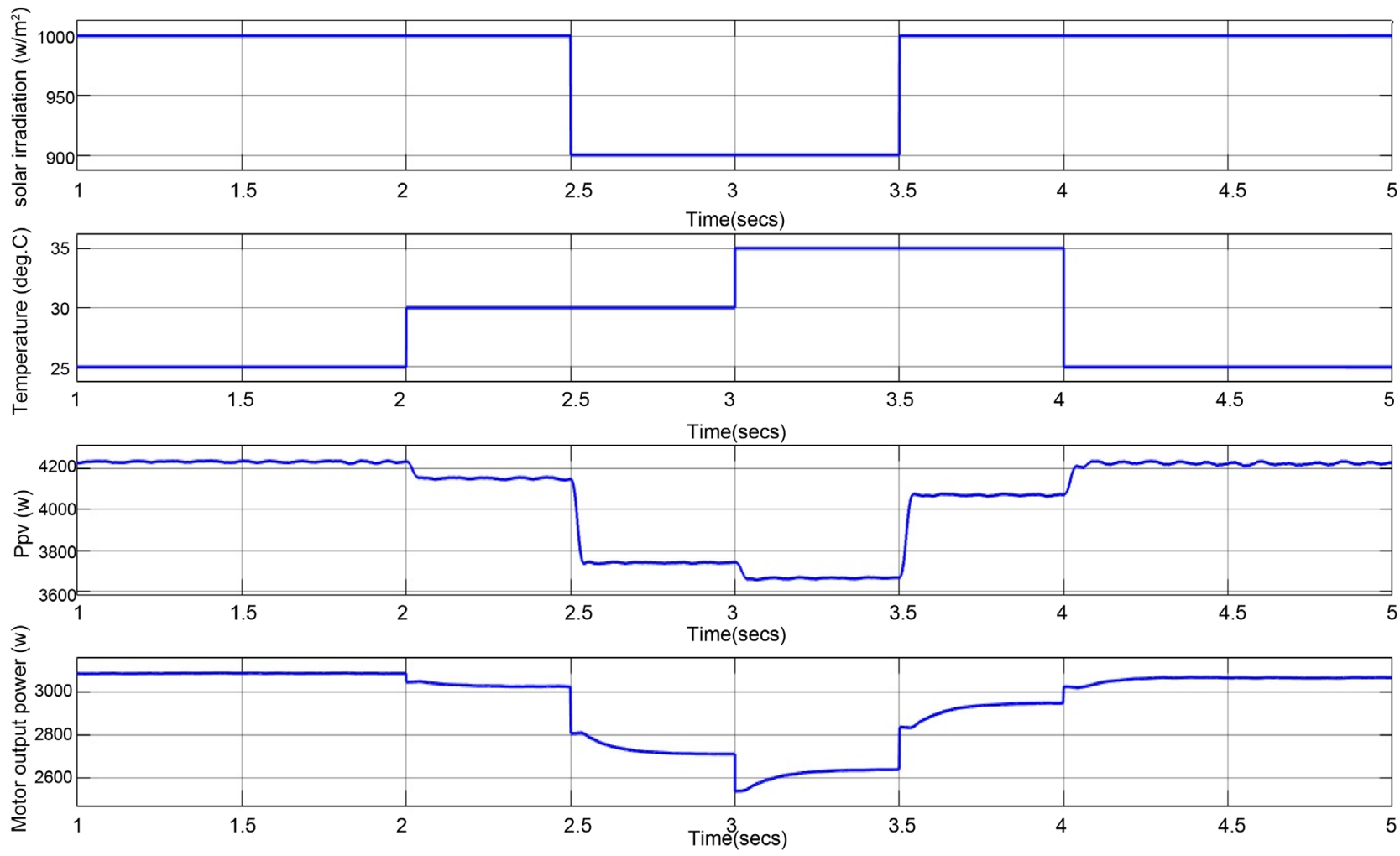

Figure 17. Simulation results of $G, T, P p v$ and Pout.

Figure 17 shows the PV power $(P p V)$ and Motor output power (Pout) with the variation of solar irradiation $(G)$ and temperature $(T)$.

Figure 18 shows the motor speed $(N)$, the resultant Electromagnetic torque $(T e)$ and head $(H)$ variation. 


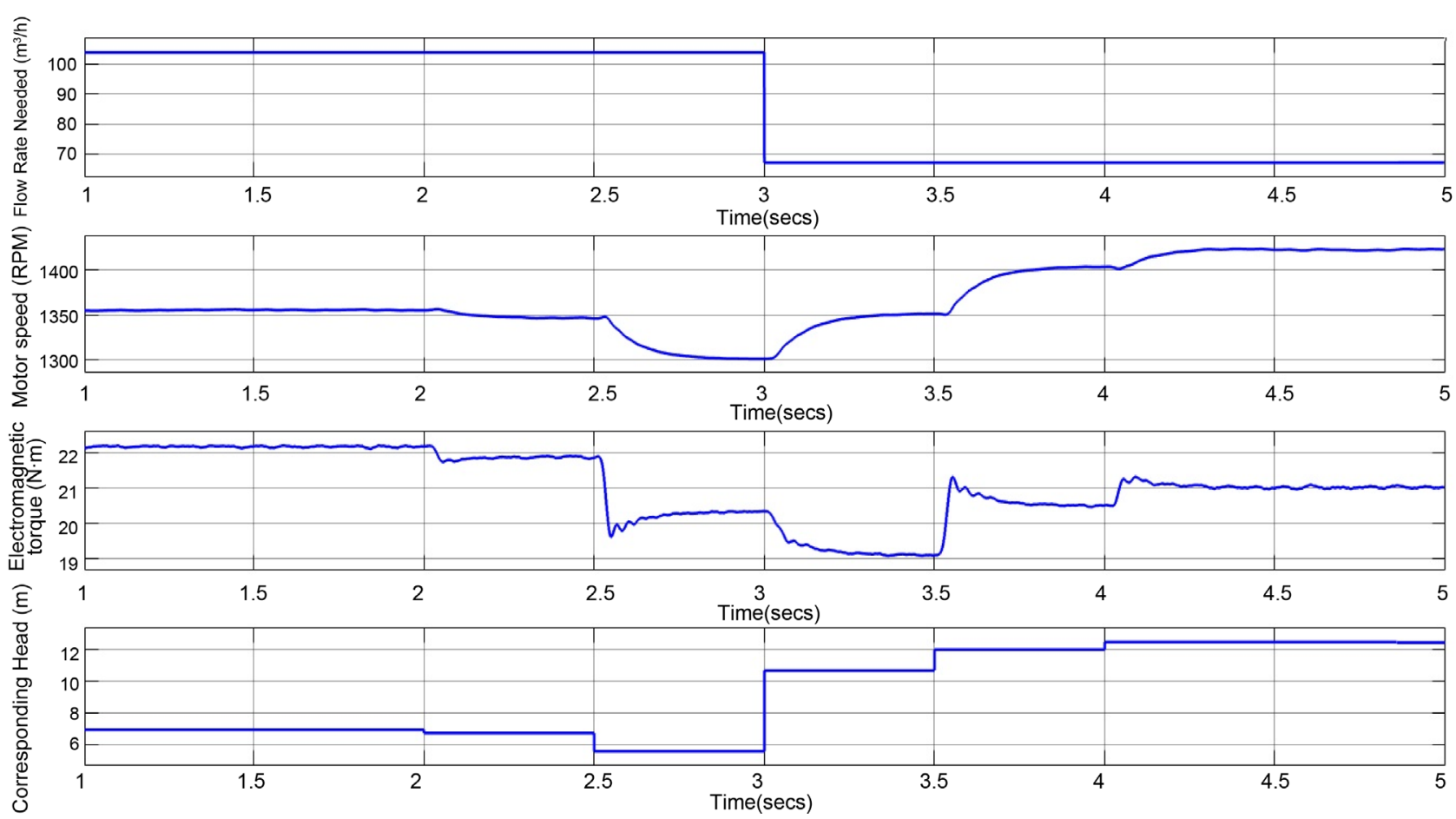

Figure 18. Simulation results of $Q, N, T e$ and $H$.

Table 7. Motor speed variation to fulfill the required pumping head.

\begin{tabular}{ccc}
\hline Time $(\mathrm{s})$ & $H(\mathrm{~m})$ & Speed (RPM) \\
\hline $0-2$ & 12.47 & 1425 \\
$2-2.5$ & 12.47 & 1419 \\
$2.5-3$ & 12.47 & 1387.8 \\
$3-3.5$ & 7 & 1285 \\
$3.5-4$ & 7 & 1331 \\
$4-5$ & 7 & 1348 \\
\hline
\end{tabular}

Figure 19 shows the PV voltage $(V p v)$, boost converter duty cycle $(D)$, outputvoltage of the boost converter (Vboost), inverter output voltage (Vinverter) and motor current (Im).

\subsubsection{Pumping Head Variation Mode}

Table 7 shows the variation of motor speed due to weather conditions variation as previously stated in Table 5 , and also due to a sudden change in pumping head. The pumping head is decreased at time ( $t=3 \mathrm{~s}$ ) from $12.47 \mathrm{~m}$ to $7 \mathrm{~m}$.

The resultant motor speed is the speed at which the pumping head $(H)$ is kept at the required value even if the weather conditions change.

Figure 20 shows the PV power $(P p v)$ and motor output power $(P o u t)$ with the variation of solar irradiation $(G)$ and temperature $(T)$.

Figure 21 shows the motor speed $(N)$, the resultant Electromagnetic torque 

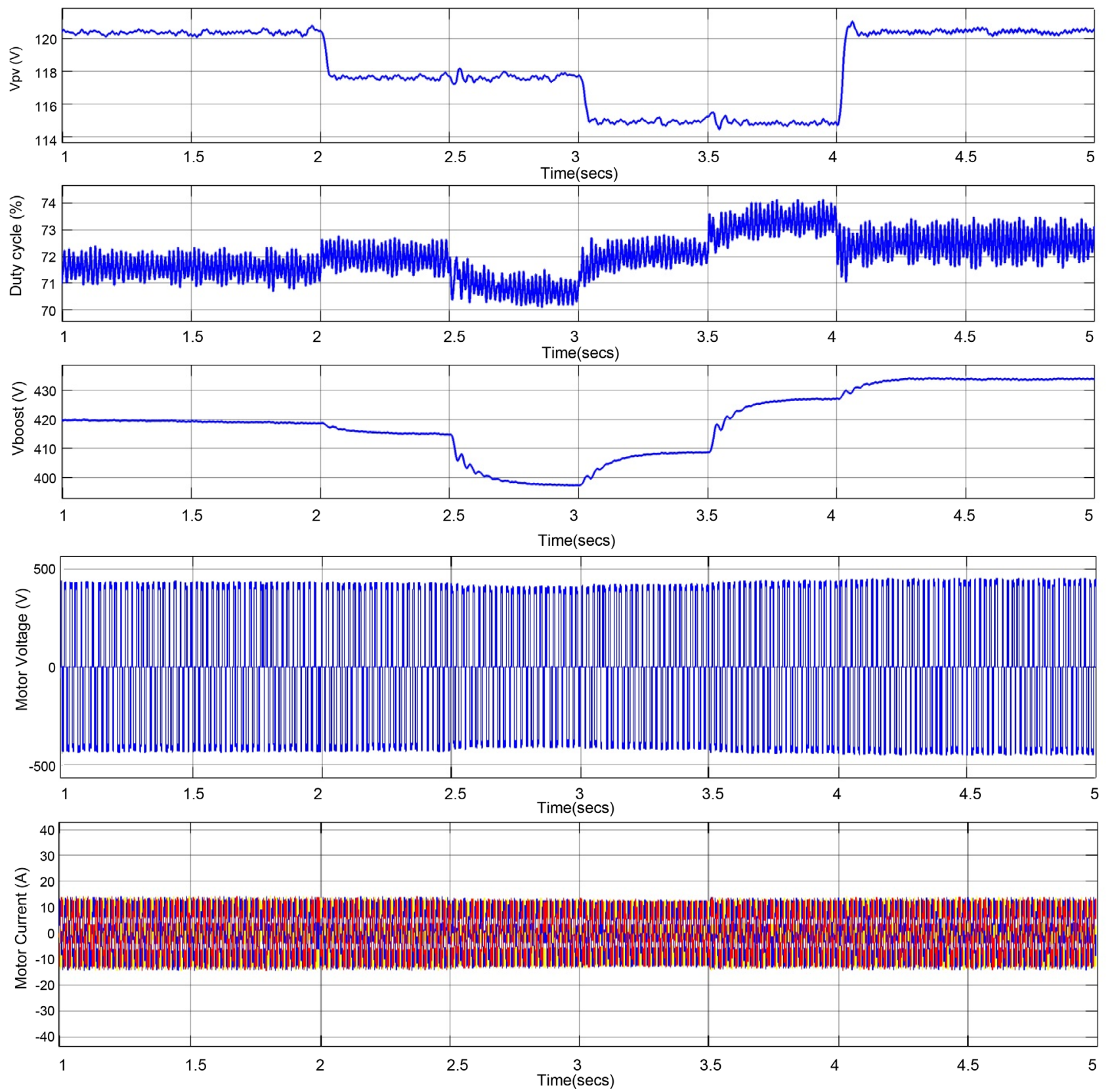

Figure 19. Simulation results of $V p v, D$, Vboost, Vinverter and Im.

$(T e)$ and flow rate $(Q)$ variation.

Figure 22 shows the $\mathrm{PV}$ voltage ( $V p v)$, boost converter duty cycle $(D)$, output voltage of the boost converter ( Vboost), inverter output voltage (Vinverter) and motor current (Im).

\section{Conclusion}

A variable speed PV water pumping system has been proposed when the power delivered to the pump motor is constant. The Affinity laws are used to achieve the required pump hydraulic performance (flow rate \& head) by varying the 

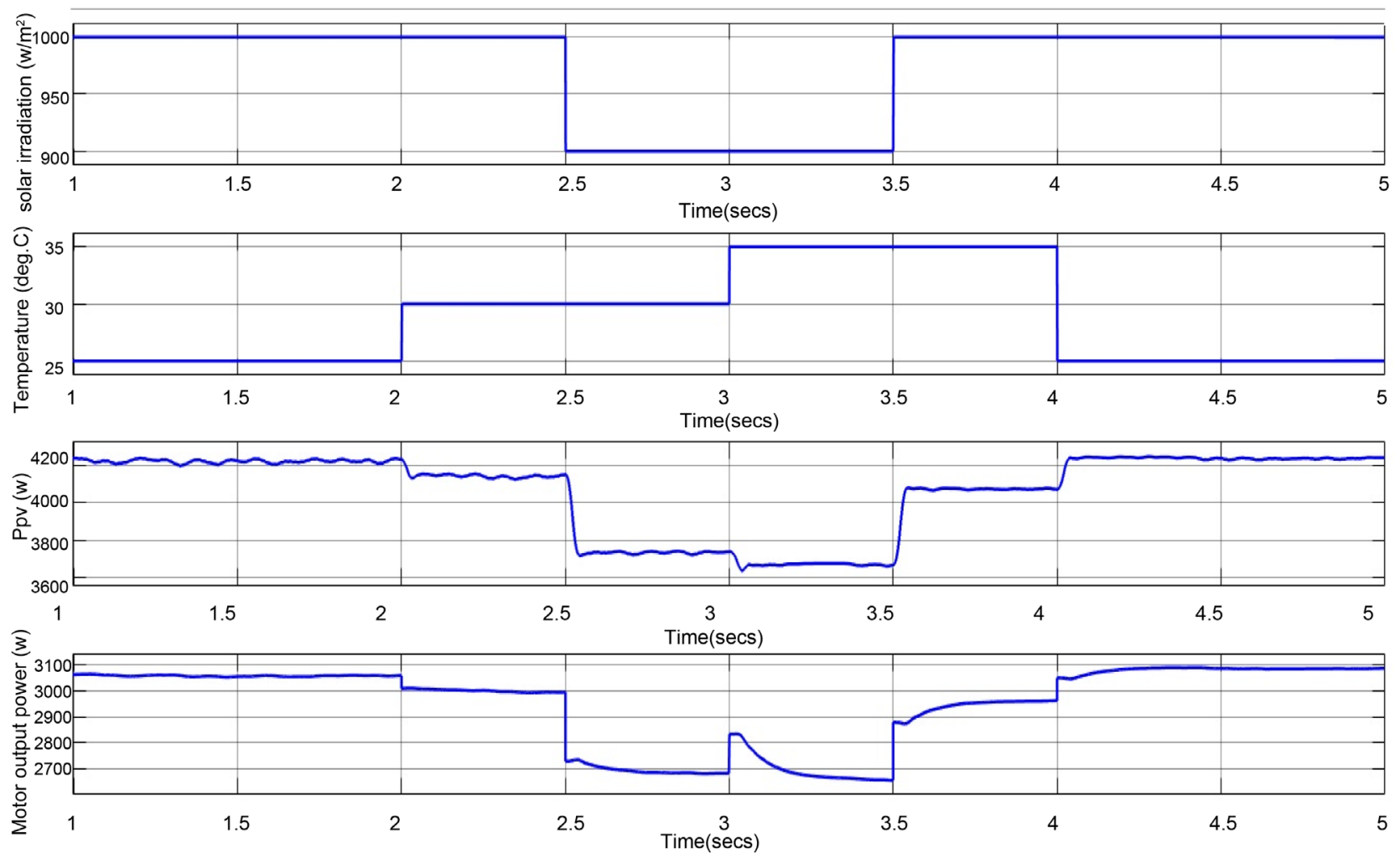

Figure 20. Simulation results of $G, T, P p v$ and Pout.
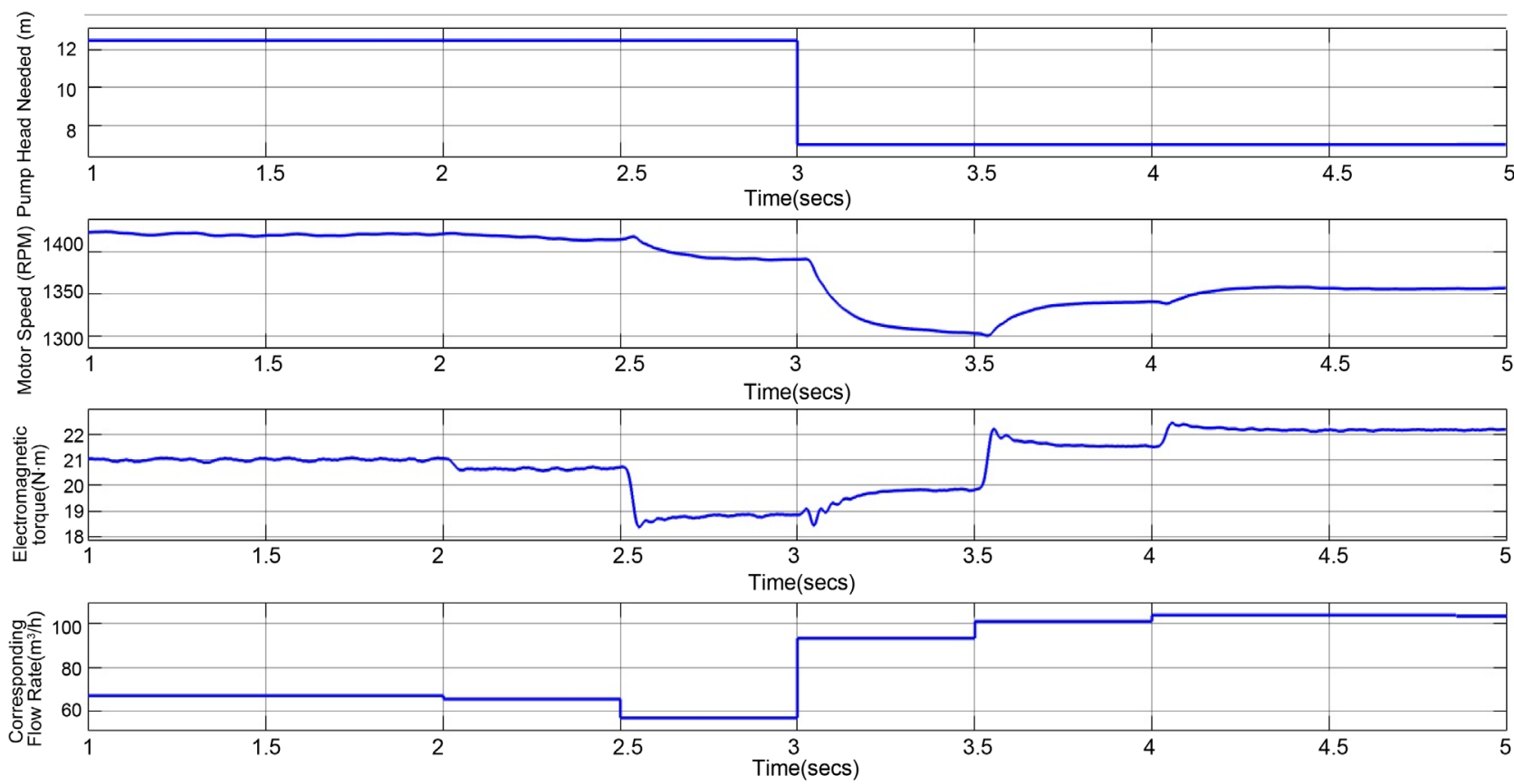

Figure 21. Simulation results of $H, N, T e$ and $Q$.

pump motor Speed. Furthermore, the Affinity laws are limited to keep the Pump speed below or equal to the rated speed of the Motor, and above the speed at which the torque load on the motor is increased over its rated torque. The 

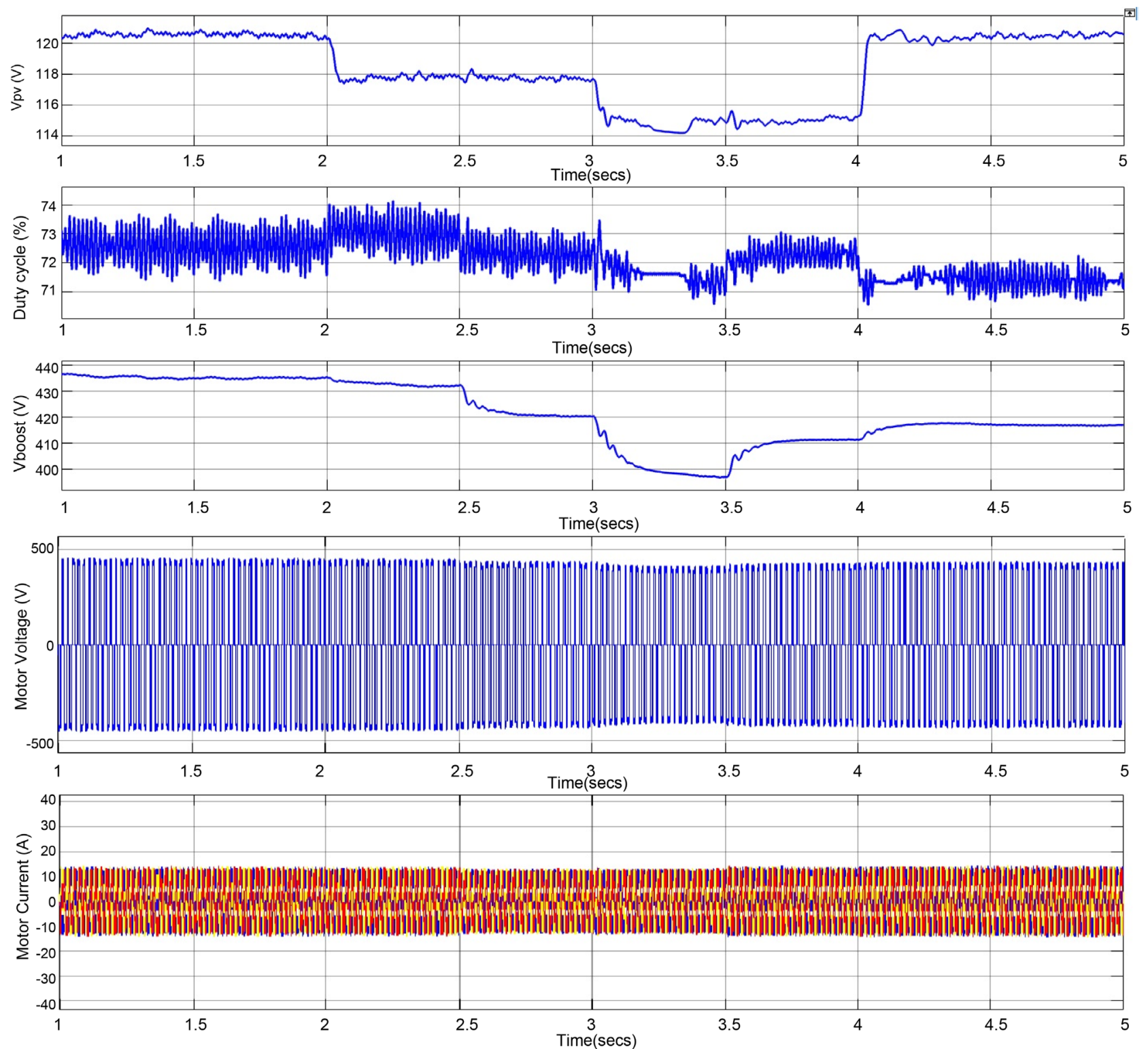

Figure 22. Simulation results of $V p v, D$, Vboost, Vinverter and Im.

system performance is simulated and analyzed for different weather and loading conditions.

\section{References}

[1] Li, G.Q., Jin, Y., Akram, M.W. and Chen, X. (2017) Research and Current Status of the Solar Photovoltaic Water Pumping System-A Review. Renewable and Sustainable Energy Reviews, 79, 440-458. https://doi.org/10.1016/j.rser.2017.05.055

[2] Chandel, S.S., Naik, M.N. and Chandel, R. (2015) Review of Solar Photovoltaic Water Pumping System Technology for Irrigation and Community Drinking Water Supplies. Renewable and Sustainable Energy Reviews, 49, 1084-1099. https://doi.org/10.1016/j.rser.2015.04.083

[3] Subudhi, B. and Pradhan, R. (2013) A Comparative Study on Maximum Power Point Tracking Techniques for Photovoltaic Power Systems. IEEE Transactions on 
Sustainable Energy, 4, 89-98. https://doi.org/10.1109/TSTE.2012.2202294

[4] de Brito, M.A.G., Galotto, L., Sampaio, L.P., de Azevedo e Melo, G. and Canesin, C.A. (2013) Evaluation of the Main MPPT Techniques for Photovoltaic Applications. IEEE Transactions on Industrial Electronics, 60, 1156-1167. https://doi.org/10.1109/TIE.2012.2198036

[5] Forouzesh, M., Siwakoti, Y.P., Gorji, S.A., Blaabjerg, F. and Lehman, B. (2017) Step-Up DC-DC Converters: A Comprehensive Review of Voltage-Boosting Techniques, Topologies, and Applications. IEEE Transactions on Power Electronics, 32, 9143-9178. https://doi.org/10.1109/TPEL.2017.2652318

[6] Elgendy, M.A., Zahawi, B. and Atkinson, D.J. (2010) Comparison of Directly Connected and Constant Voltage Controlled Photovoltaic Pumping Systems. IEEE Transactions on Sustainable Energy, 1, 184-192. https://doi.org/10.1109/TSTE.2010.2052936

[7] Caracas, J.V.M., de Carvalho Farias, G., Teixeira, L.F.M. and de Souza Ribeiro, L.A. (2014) Implementation of a High-Efficiency, High-Lifetime, and Low-Cost Converter for an Autonomous Photovoltaic Water Pumping System. IEEE Transactions on Industry Applications, 50, 631-641. https://doi.org/10.1109/TIA.2013.2271214

[8] Vitorino, M.A., Correa, M.B.R., Jacobina, C.B. and Lima, A.M.N. (2011) An Effective Induction Motor Control for Photovoltaic Pumping. IEEE Transactions on Industrial Electronics, 58, 1162-1170. https://doi.org/10.1109/TIE.2010.2054053

[9] Ferreira, F.J.T.E., Fong, J.A.C. and de Almeida, A.T. (2011) Ecoanalysis of Variable-Speed Drives for Flow Regulation in Pumping Systems. IEEE Transactions on Industrial Electronics, 58, 2117-2125. https://doi.org/10.1109/TIE.2010.2057232

[10] Igor, J.P.M., Karassik, J., Cooper, P. and Heald, C.C. (2008) Pump Handbook. 4th Edition, McGraw-Hill, New York.

[11] Marchi, A., Simpson, A.R. and Ertugrul, N. (2012) Assessing Variable Speed Pump Efficiency in Water Distribution Systems. Drinking Water Engineering and Science, 5, 15-21. https://doi.org/10.5194/dwes-5-15-2012

[12] Khader, S. and Daud, A. (2013) PV-Grid Tie System Energizing Water Pump. Smart Grid and Renewable Energy, 4, 409-418. https://doi.org/10.4236/sgre.2013.45047

[13] Chandrasekaran, N. and Thyagarajah, K. (2014) Simulation and Experimental Validation of AC Motor and PMDC Motor Pumping System Fed by Photovoltaic Cell. Indian Journal of Engineering and Material sciences, 21, 93-103.

[14] Altas, I.H. and Sharaf, A.M. (2007) A Photovoltaic Array Simulation Model for Matlab-Simulink GUI Environment. International Conference on Clean Electrical Power, Capri, 21-23 May 2007, 341-345. https://doi.org/10.1109/ICCEP.2007.384234

[15] Auxin Solar. AXN-P6T170. https://solarhub.com/product-catalog/pv-modules/2377-AXN-P6T170-Auxin-Solar

[16] Mohan, N., Undeland, T.M. and Robbins, W.P. (2003) Power Electronics: Converters, Applications, and Design. 3rd Edition, Wiley, New York.

[17] Electromagnetic Compatibility (EMC)-Part 3-2: Limits-Limits for Harmonic Current Emissions, IEC 61000-3-2:2014.

[18] Fitzgerald, A.E., Kingsley Jr., C. and Umans, S.D. (2002) Electric Machinery. 6th Edition, McGraw-Hill, New York.

[19] IEEE Standard Test Procedure for Polyphase Induction Motors and Generators. IEEE Std 112-2004.

[20] Haque, M.H. (1993) Estimation of Three-Phase Induction Motor Parameters. Elec- 
tric Power Systems Research, 26, 187-193.

https://doi.org/10.1016/0378-7796(93)90012-4

[21] ABB (June 2016) Low Voltage General Performance Motors. https://library.e.abb.com/public/4ca17f3cdb064c97bb990b73673a038f/OBJ_DCL-49 -003_new.pdf

[22] $\mathrm{Wu}, \mathrm{B}$. (2006) High-Power Converters and AC Drives. Wiley-IEEE Press, New York. https://doi.org/10.1002/0471773719

[23] Bose, B.K. (2002) Modern Power Electronics and AC Drives. Prentice Hall, Upper Saddle River.

[24] Kazmierkowski, M.P. and Malesani, L. (1998) Current Control Techniques for Three-Phase Voltage-Source PWM Converters: A Survey. IEEE Transactions on Industrial Electronics, 45, 691-703. https://doi.org/10.1109/41.720325

[25] Bose, B.K. (1990) An Adaptive Hysteresis-Band Current Control Technique of a Voltage-Fed PWM Inverter for Machine Drive System. IEEE Transactions on Industrial Electronics, 37, 402-408. https://doi.org/10.1109/41.103436

[26] ALFA LAVAL (2008) LKH-/LKHP-/LKHI-60, $50 \mathrm{~Hz}$. http://www.alfacas.com/Pumps/Centrifugal_Pumps/21_CentrifugalPump_PC_en.pdf

[27] Chouder, A. and Silvestre, S. (2009) Analysis Model of Mismatch Power Losses in PV Systems. Journal of Solar Energy Engineering, 131, Article ID: 024504.

https://doi.org/10.1115/1.3097275 